\title{
"Performance Can Reveal Paths Forward": Interview with Amanda Eubanks Winkler
}

\author{
Klára Škrobánková, Pavel Drábek
}

\begin{abstract}
Amanda Eubanks Winkler is a Professor of Music History and Cultures and Chair of the Department of Art and Music Histories at Syracuse University. Her research focuses on English theatre music of the seventeenth, eighteenth, and twentieth centuries. She was the Co-Investigator on Performing Restoration Shakespeare (https://www. qub.ac.uk/schools/ael/Research/ResearchinArts/ResearchImpact/PerformingRestorationShakespeare/), a project funded by the Arts \& Humanities Research Council, UK (2017-2020) and is a General Editor for The Collected Works of John Eccles (A-R Editions). Prof. Eubanks Winkler has published on a range of topics, including the relationships among musical, spiritual, and bodily disorder; musical depictions of the goddess Venus; the gendering of musical spirits; and the intersection of music and politics. More recent work has engaged with performance studies and practicebased research, including workshops that staged excerpts of Davenant's Macbeth and Gildon's Measure for Measure (Folger Theatre, Washington DC) and Middleton's The Witch (Blackfriars Conference, Staunton, VA). As part of the Performing Restoration Shakespeare project, she served as music director for a workshop of the Restorationera Tempest (Sam Wanamaker Playhouse, Shakespeare's Globe, London) and more recently she co-led a workshop for scholars and served as a consultant for a full professional production of Davenant's Macbeth, staged at the Folger Theatre, Washington DC. Prof. Eubanks Winkler's most recent book, Music, Dance, and Drama in Early Modern English Schools (https://www.cambridge.org/core/books/music-dance-and-drama-inearly-modern-english-schools/95C0580997C7891B54031E0845F500F9), appeared with Cambridge University Press in 2020. Shakespeare in Performance: Sir William Davenant and the Duke's Company, co-authored with Richard Schoch, is forthcoming with Arden Shakespeare/Bloomsbury in 2021.
\end{abstract}

This article was supported by the Czech Science Foundation project GA19-07494S. English Theatre Culture 1660-1737. 


\section{(1) "Bridging the Divides"}

[KŠ / PD] You have ample practical experience with stagings of Restoration adaptations of Shakespeare, and especially the trickiest titles - the operatic versions of The Tempest and Macbeth. As texts, these are fascinating treasure troves of historic tastes, predilections, and genres. Another thing is staging them today. That is, aesthetically speaking, a battlefield of contending expectations and our present day tastes, predilections, and genres. What is your experience of tackling this contentious topic? What are your findings and observations? How have you bridged the divides? Can these explorations be made accessible to non-academic audiences, and if so how?

[AEW] Restoration Shakespeare seems designed to offend modern sensibilities. Adapters had the gall to change the Bard's immortal words. Playwrights such as William Davenant and John Dryden added new characters and Nahum Tate gave King Lear a happy ending. Some of these adaptations - Macbeth and The Tempest among them - included substantial scenes of music and dancing, hollowing out Shakespeare's poetry to make space for spectacle and song. For these reasons, critics from the eighteenth century onwards viewed these adaptations as desecrations of sacred texts. I look at things differently. If something was popular, if it worked in the theatre and won over audiences, I want to understand it on its own terms. That's why Richard Schoch and I developed Performing Restoration Shakespeare. Our practicebased project posits that performance is the best heuristic for understanding the ontology of Restoration Shakespeare, why it appealed then, and why it appeals now. Indeed, the special charm of Restoration Shakespeare is incomprehensible if one only consults the printed quartos. The spoken dialogue lacks the evocative poetic imagery found in Shakespeare. The sung portions appear only as lyrics, unsounded. And the lavish spectacle (dancing, changeable scenery, costumes, and, in later productions, machine effects) are described in stage directions, but these events must be conjured in the imagination of the reader.

In order to understand Restoration Shakespeare, its characteristic intermedial elements must be in place; however, beyond this brief, Performing Restoration Shakespeare used a flexible approach to performance. Historical knowledge served as a point of departure rather than a set of directives. We took this looser approach to historicity because part of our aim was to discover ways of staging Performing Restoration Shakespeare today, and many theatre companies (and opera companies) are not willing to or do not have the requisite in-house expertise to stage an Original Practices production. (Original Practices referring to the playing style developed at Shakespeare's Globe that sought to recapture "original" historical playing styles).

Our workshop staging of The Tempest at the Wanamaker Playhouse, Shakespeare's Globe, presented a different set of issues than the Equity production of Macbeth at the Folger Theatre. In both cases, we learned quite a bit from our audiences about what made Restoration Shakespeare work in the late seventeenth century and how it might work today. In fact, we collected data in face-to-face interviews and via 
anonymous surveys to better understand audience reception. Our audience included academics and non-academics in both locations.

For instance, The Tempest workshop did not include spectacle or costumes, and the absence of these elements was keenly felt by our audience, particularly in our staging of the Masque of Neptune, a scene that included lavish machines, vivid costumes, and dance when it was first performed at Dorset Garden Theatre in 1674. Staging it without spectacle and costumes allowed us to better ascertain the importance of these elements to facilitate audience understanding. Audiences also felt that stylized movement was needed, to underscore the antiquarianism of a masque populated by Greco-Roman deities.

Conversely, Macbeth did include spectacle (furnished by arc lights and projected shadows), Restoration-era costumes, period music, and Davenant's text; however, the director, Robert Richmond, imposed a Regietheater framing device: he set the action in 1666 in Bedlam hospital. The actors were the patients in the asylum, and, in an ironic twist, the despotic and cruel hospital administrator played the saintly Duncan. Richmond instituted this frame because he was worried about staging Davenant's adaptation, instead of the Shakespearean original. He also worried that the singing and dancing witches would detract from the grim tragedy of Macbeth. Where Samuel Pepys saw "strange perfection" in Macbeth's "divertissement" Richmond saw trouble. Shakespeare was timeless and transcendent: Davenant was not.

Restoration Shakespeare has frequently been seen as a defilement of Shakespeare's sacred texts, so Richmond's squeamishness was somewhat understandable. Although the Performing Restoration Shakespeare project paid for a lot of the production costs, the Folger had committed significant financial resources to the enterprise. Staging Davenant was a leap of faith for them, particularly as the Folger audiences are accustomed to watching Shakespeare, not adaptations of Shakespeare. Thankfully for all involved, Davenant's Macbeth was a hit - it sold out for its entire run and proved popular, especially with younger audience members seeking a novel theatrical experience. The Folger performances proved that Restoration Shakespeare could be enjoyed by audiences today. On an intellectual level, staging Macbeth revealed additional information about the ontology of Restoration Shakespeare. First, Davenant knew what he was doing. His syncretic combination of music, dance, text, and spectacle worked then, and it works now. Although the Bedlamite concept had a mixed reception among audience and critics, the elements that made Restoration Shakespeare distinctive were almost universally praised. In our surveys audiences particularly admired the witches' music by John Eccles, which had been edited by me, and the period music compilation score, which had been selected by Robert Eisenstein, and was played "live" by the band in a gallery above the stage. Apparently, very little needs to be done to make Restoration Shakespeare appealing, if one respects its dramaturgy. 


\section{(2) Sacred History and Its Profanations}

[KŠ / PD] Discussions of Restoration adaptations of Shakespeare often end up hovering around a certain bemusement or condescending nod at the implicit failure of Restoration theatre to appreciate the greatness of the great national poet. Implicitly, these adaptations are viewed as inferior, naive or even profane. However, the stakes here seem to be not just a critical appreciation of theatre history but rather the sacredness of our cultural identity with the cult of Shakespeare and the Shakespearean text at its heart. Would you agree with this view? How do you negotiate these cults while working with adaptations that are often played down with pejorative assessment? What are your criteria for assessment of these versions? What role does music and its adaptability play in these contexts?

[AEW] Although some academics and laypeople view Restoration Shakespeare with a jaundiced eye as a debasement of the great Bard, there has been increasing interest in seeing it on its own terms - a trend that is perhaps a manifestation of broader criticisms of the canon and its attendant taste and value judgments. One might say that now is the perfect time to stage Restoration Shakespeare, for, as we experienced, it can bring new audiences to the theatre, audiences allured by its "divertissement."

Restoration Shakespeare captures a past aesthetic, a performance style that spoke to people in the late seventeenth and early eighteenth century; thus, for it to be Restoration Shakespeare, for it to retain its ontology, one must commit to using the Restoration-era playtext and, if it's one of the operatic adaptations (i.e., Macbeth, The Tempest, The Fairy Queen, Measure for Measure), the surviving period score. This mandate aligns with practices in the opera house; one would never dream of rewriting or replacing Verdi's score for La Traviata or Mozart's score for Le nozze di Figaro, as the music is an inextricable component of the work. Beyond these essential requirements, there are numerous possibilities for staging Restoration Shakespeare successfully. One could lean into historicity and take an Original Practices approach, complete with period music, baroque dance, machines, perspective scenery, and historically informed gesture. Opera companies might be best equipped to take on such a project. Another possible mode of production is to update the setting but keep the Restoration text and period score. Jonathan Kent's Glyndeborne production of The Fairy Queen (2009) took a deliberately atemporal approach: the rustic mechanicals were mid-twentieth-century janitors, the fairies looked vaguely Goth, with their black outfits and wings, and the singers and dancers and the quartet of lovers wore costumes from the seventeenth and eighteenth centuries. There was also ample baroque spectacle - trap doors, flying on wires, and a majestic machine, as well as raunch (a coterie of libidinous bunnies). Thus, in Kent's conception, Restoration Shakespeare was both of his time and of all times. Admittedly, Kent's production did not come cheaply and thus required the resources of the opera house to pull off. A more modest production along the same lines might also be mounted, such as the Macbeth at the Folger, which included the key elements of Restoration Shakespeare's dramaturgy - text, music, dance, and spectacle - without breaking the proverbial bank. 


\section{(3) Interdisciplinarity and Its Discontents}

[KŠ / PD] You work across a number of disciplines - from musicology, through theatre history and literary studies, to performance practice (theatre, music, dance). Each of these disciplines has its routines, specifics and proclivities, and they don't often blend. It is specifically in Restoration theatre that this interdisciplinarity finds its perfect ground. How do you combine the disciplinary methods, horizons of expectations, and agendas? Would you say that part of the challenge of Restoration theatre is its "Gesamtkunstwerk-ness" avant la lettre? What paths and strategies do you have to address these disciplinary discontents?

[AEW] I have spent my career working at the nexus of multiple fields (musicology, theatre history, literary studies, performance studies, performance practice, and gender studies). To be taken seriously as an interdisciplinary scholar, to gain the respect of peers, one must be completely conversant with the requisite methodologies and scholarly literature in multiple fields. The risk of missing something is high and the pitfalls are numerous, but the rewards are vast. My approach has proved intellectually generative, but it is also inherently time consuming - that is the major drawback of interdisciplinary work.

Each field has its idiosyncrasies, and when I write I am always cognizant of my intended audience. Although my training is as a musicologist, I rarely include jargonfilled musical analyses in my work. Many of my readers will not be musically literate, so I've found ways of communicating my findings to a non-musical audience.

Sometimes my practice-based research has substantially shaped other, unrelated scholarly projects. Working on the Restoration Shakespeare project as well as other practice-based projects reminded me of the ways the performance can profoundly shape interpretation, how it can alter or unsettle the text. It also reminded me that performance is mutable - there is no such thing as an "original." All these observations directly fed into the approach that I used in my most recent book, Music, Dance, and Drama in Early Modern English Schools, where I deployed a methodology that "minds the gaps" in the archive. Much of the repertory for school-based entertainments exists only in fragmentary or incomplete forms. Even when the complete work does exist, we cannot fully recover information about the children who performed these masques, operas, "balls," and plays. Thus, I needed to create a methodology that acknowledged absence and silence. I needed to think creatively about how to put flesh on the bones of my archival sources. In order to do that, I thought about my archive as repertory, as performances, and drew upon a range of performance studies scholarship as well as theatre history and musicology to inform my approach. 


\section{(4) Theatre Practice as Research}

[KŠ / PD] Practice-as-research (PaR) or practice-based research is a relatively new phenomenon but well established in many countries and disciplines. What are the challenges for you and your past or present projects? What experience do you have with PaR as a heuristic strategy? What kind of research findings has PaR yielded for you?

[AEW] Practice-based research is a powerful heuristic for answering questions that only performance can answer. What might be revealed by staging a work with all its constituent parts intact? How does casting a particular type of performer affect meaning? Sometimes the performance itself is the research output, but often the research spills over into the written word, as one articulates what one has learned in prose.

Staging Restoration Shakespeare has revealed several key things. We know that actorsingers in addition to trained vocalists from the Chapel Royal took part in the $1674 \mathrm{Tem}$ pest, so we followed these casting practices in our Performing Restoration Shakespeare workshop at the Wanamaker Playhouse. For the roles of Ariel and Ferdinand, two parts that would have been played by actor-singers on the Restoration stage, we cast Emily Barber and Domenic Brewer, performers with pleasant voices and solid acting chops. Their skill-set served them well as they performed their echo song, "Go thy way," which was newly added to the Restoration version of The Tempest. The musically simple duet only works if the performers have sufficient charisma and stage presence - luckily Dom and Emily are absolutely charming, and this scene proved to be one of the most appealing to our audiences at the Globe. Professional singers were required for the more difficult musical scenes - the Masque of Devils and the Masque of Neptune. These interludes were performed by professional singers on the Restoration stage, including some imported by kingly decree from the Chapel Royal. By casting the appropriate performers for each kind of musical scene, by following Restoration practices, we confirmed the wisdom of their approach. Sometimes a good singer who is a great actor is the best choice, but sometimes trained musicians must take center stage.

Performance and academia are two very different worlds, and performers sometimes look at scholars with suspicion, as they associate us with the dreaded critic, or, worse, a Polonius-style pedant. Conversely, academics sometimes use performers as tools devoid of agency, a vessels through which they might test their pet theories. Each workshop - the Folger workshop in 2014, which supplied the proof of concept for the larger Performing Restoration Shakespeare project; the 2017 Wanamaker workshop; and the 2018 Folger workshop - was structured differently and presented a different set of problems and opportunities.

In the 2014 workshop we staged scenes from Davenant's Macbeth together with music by Richard Leveridge (1702). For this enterprise, we brought together actors from the Folger Theatre, the Folger Consort, and a group of scholars. We learned a great deal about best practices for scholar-artist collaboration from this workshop. Despite our intentions, after the first day the performers were left feeling like props for the scholars, rather than full-fledged collaborators. To reset the tone of our workshop, we began 
the beginning of the second day with a feedback session with the artists, so they could share their knowledge about the challenges and pleasures of performing Restoration Shakespeare.

Another thing we learned from this 2014 event was that scholars needed coaching on how to give "playable" instructions to performers. Historical background might be valuable, but it doesn't necessarily translate into something an actor or musician can execute. At the beginning of our 2017 workshop at the Wanamaker, we therefore began with a session to discuss the kinds of feedback that performers would find useful. We also made clear to the performers from the outset that they were full collaborators in the process. Their knowledge playing Restoration Shakespeare was placed on an equal level with the historical information supplied by the scholars. For that reason, some aspects of the Wanamaker workshop went more smoothly than the 2014 workshop. But the 2017 workshop presented another set of challenges. We had a few days to rehearse scenes with the scholars before performing them before a paying audience at the Wanamaker. Because we were pressed for time and because our scholarly team was large, not everyone got an opportunity to supply feedback, which caused disappointment for some.

In 2018 we corrected course again. We wanted the scholars to be sufficiently "heard" so we admitted fewer people, expanded our event to two weeks, and frontloaded the experience with two scholarly mini-conferences with the cast and production team present: one on music and one on theatre. We also set clear ground rules for scholar/artist interaction. Because our Macbeth was a professional Equity production with a director there were limits to our input, but because we set a clear expectation with our scholars they were largely satisfied by the experience and the data, the scholarly grist, they received from the experience. 
